\title{
Occurrence of priority trace metals in tomatoes (Solanum lycopersicum L.) from some areas of Uasin Gishu County, Kenya
}

\author{
Decrah Moraa Nyangena ${ }^{\mathrm{a}, \mathrm{b}}$, James Oagare Arasa ${ }^{\mathrm{a}}$, Timothy Omara ${ }^{\mathrm{a}, \mathrm{b}, \mathrm{c}^{*}}$ \\ ${ }^{a}$ Department of Chemistry and Biochemistry, School of Sciences and Aerospace Studies, Moi \\ University, Uasin Gishu County, P. O. Box 3900, Eldoret, Kenya. \\ ${ }^{b}$ Africa Centre of Excellence II in Phytochemicals, Textiles and Renewable Energy (ACE II PTRE), \\ Moi University, Uasin Gishu County, P. O. Box 3900, Eldoret, Kenya. \\ ${ }^{c}$ Department of Quality Control and Quality Assurance, Product Development Directory, \\ AgroWays Uganda Limited, Plot 34-60, Kyabazinga Way, P. O. Box 1924, Jinja, Uganda. \\ *prof.timo2018@gmail.com,prof.timo2018@mu.ac.ke
}

Keywords: Cancer risk, Eldoret, Estimated daily intake, Target hazard quotient.

This study determined the concentration of zinc, lead and cadmium in tomatoes consumed in some areas of Uasin Gishu, Kenya. Samples were taken in quintuplicate from Huruma and Bahati estates (Eldoret) and Chebaiywo (Kesses) and their metalliferous content were determined by atomic absorption spectroscopy. All samples had detectable levels of trace metals, with lead recording the highest concentration of $43.20 \pm 0.31 \mathrm{mg} / \mathrm{kg}$. Zinc concentrations were below WHO guidelines. Daily intakes ranged from $8.25 \times 10^{-4}$ to $2.59 \times 10^{-1} \mathrm{mg} / \mathrm{kg} / \mathrm{day}$. Though there are no probable cancer risks, hazard quotients indicated that deleterious health effects could arise from daily consumption of tomatoes.

\section{Introduction}

Vegetables, fruits and spices are inevitable recipes of nutritional therapies because they are dietary sources of health-enhancing fibers, minerals, anthocyanins and vitamins that play various metabolic roles in humans [1]. In several towns in Africa, peri urban cultivation is done on trace metal adulterated soils or wastewaters are used for watering plants which may enhance translocation of toxic chemicals to edible plant parts [2]. Trace metal accumulation in soils and their subsequent transfer to plants, and finally humans has been a subject of obsessive research due to the food safety issues and potential health risks from their consumption $[3,4]$. Trace metals in soils may be from natural sources or anthropomorphic contributions [5-7]. Anthropomorphic inputs are due to industrialization and agronomic practices such as incineration activities, improper waste management, industrial effluents, automotive fumes, and inadvertent utilization of agrochemicals and sewage sludge on farms [4, $8]$. 
One known exposure route to toxic metals is via intake of vegetables and fruits cultivated on trace metal contaminated soils $[2,4]$. Heavy metals are readily phytoaccumulated in edible plant parts regardless of their initial concentrations in the soil $[4,9]$. Health risks originating from intake of individual trace metals in foodstuffs has been extensively explored. Nevertheless, heavy metals co-exist in environmental matrices, and the probable risks estimated on the basis of a single metal is inadequate to prognosticate the health risks compounded by co-occurrence of heavy metals [4].

Few studies previously reported on the occurrence of potentially harmful trace metals in organ meat, animal feeds, vegetables, some fruits (oranges and mangoes), soils and water in Uasin Gishu County, Kenya [10-14]. However, tomatoes which is one of the dietetic staples have not been investigated. Against this background, we analyzed tomatoes from Eldoret and Chebaiywo village for their presupposed contamination with zinc, lead and cadmium.

\section{Experimental part}

\section{Collection and analysis of samples}

Tomato fruits were collected in quintuplicate from randomly selected sites in Huruma estate (0.526206, 35.243865) and Bahati estate $(0.528352,35.2395731)$ of Eldoret town and Chebaiywo village $(0.283736,35.280623)$, Kesses constituency. They were stored in clean polyethylene bags and transported to the laboratory within 3 hours of collection. The fruits were washed thoroughly under running tap water followed by double distilled water to preclude contamination by pesticides, fertilizers and dust. They were blotted dry with tissue paper.

The samples were dried in an oven at $70{ }^{\circ} \mathrm{C}$ for 72 hours, weighed and ground. Aliquots (0.5 g) were digested with $4 \mathrm{ml}$ of concentrated nitric acid. The resultant solutions were left to cool at room temperature for 2 hours. They were transferred into an oven where they were heated at $100^{\circ} \mathrm{C}$ for 1 hour and then $170^{\circ} \mathrm{C}$ for 5 hours. After digestion, the samples were transferred to a hot plate at $105^{\circ} \mathrm{C}$ to evaporate excess acid until near dry. The residues were diluted with deionized water in $50 \mathrm{ml}$ volumetric flasks and kept at $4{ }^{\circ} \mathrm{C}$ until commencement of analysis [3]. Trace metal concentrations were quantified using a Shimadzu spectrophotometer (Model AA 6300, Shimadzu Corporation, Japan). Analytical grade cadmium $(\mathrm{Cd})$, zinc $(\mathrm{Zn})$, and lead $(\mathrm{Pb})$ nitrate salts were used to prepare standard working solutions with concentrations between 0.05 and $100 \mathrm{mg} / \mathrm{L}$. The spectrophotometer was turned on 2 hours before commencement of heavy metal quantification. The respective cathode lamps were set with wavelengths at 228.8, 232.0 and $213.9 \mathrm{~nm}$ for $\mathrm{Cd}, \mathrm{Pb}$ and $\mathrm{Zn}$ respectively. The flame used in the analysis was from combustion of air and acetylene. Quintuplicate set of heavy metal standards were run and the absorbances obtained were used to generate respective metal standard curves. Quality control was assured 
using spiked samples analyzed for every 1 in 10 samples. Recovery percentages recorded ranged from 98.8 to $101.4 \%$. Analytical blanks were also determined and were used to correct the concentrations computed. All samples were analyzed at least in duplicate and the absorbances were used to calculate the trace metal concentrations from the respective heavy metal standard curves. The concentrations in $\mathrm{mg} / \mathrm{L}$ were converted to $\mathrm{mg} / \mathrm{kg}$, the standard unit for solid foods, to enhance comparison of the results with set compliance guidelines [15].

\section{Human health risk assessment}

Exposure assessment is toxicologically ascribed as a robust tool for relating risk factors to human health due to dietary intake of toxins. The estimated daily intake (EDI) for ingestion of tomatoes was computed for both children (representing a sensitive group) and adults (representing the general population) to approximate probable exposure through intake of tomato fruits using Equation 1 [15-17].

$\operatorname{EDI}(\mathrm{mg} / \mathrm{kg})=\frac{\mathrm{F} \times \mathrm{C} \times \mathrm{E}_{\mathrm{F}} \times \mathrm{E}_{\mathrm{D}}}{\mathrm{T} \times \mathrm{W}}$

From which $\mathrm{F}$ is the tomato fruit ingestion rate $=$ $0.09 \mathrm{~kg} /$ person/day [4], C = trace metal concentration in the edible fruit parts, $\mathrm{EF}$ is the exposure frequency $=365$ days/year, due to daily intake of tomatoes by humans, ED is the exposure duration $=66.7$ years for Kenyans [18], $T$ is the average exposure time which is the product of $\mathrm{ED}$ and $\mathrm{EF}[16,19]$, and $\mathrm{W}$ is average body weight which was taken as $60 \mathrm{~kg}$ and $15 \mathrm{~kg}$ for adults and children respectively.

The health risk index, defined as the total risk of a non-carcinogenic element was computed employing the target hazard quotient (THQ) method (Equation 2) [6, 15].

$\mathrm{THQ}=\frac{\text { Estimated daily intake }}{\text { Heavy metal reference oral dose }}$

The oral reference doses in $\mathrm{mg} / \mathrm{kg}$ for $\mathrm{Zn}, \mathrm{Pb}$ and $\mathrm{Cd}$ are respectively $0.03,0.004$ and 0.001 [20]. Further, exposure to more than one toxic heavy metal results in summative effects so that the total THQ (hazard index, HR) was obtained as the arithmetic sum of the individual metal THQs (Equation 3) [2, 4, 6].

$\mathrm{HR}=T H Q_{Z n}+T H Q_{P b}+T H Q_{C d}$

For THQ lower than unity, no probable health risks from exposure to heavy metals is expected. On the other hand, THQ equal to or higher than unity indicates that the exposed population may experience a non-carcinogenic effect [21].

The carcinogenic risk, defined as the product of the ingestion cancer slope factor and the EDI was computed for dietary intake of both $\mathrm{Cd}$ and $\mathrm{Pb}$ by adults and children [6].

\section{Statistical analysis of results}

The results of the analyses were entered into Microsoft Excel 365 and subjected to preliminary analysis. The data were checked for normal distribution prior to statistical evaluation using Kolmogorov-Smirnov test and subsequently presented as means of 
quintuplicates with errors as standard deviations attached. Paired $t$ test was used to identify any significant differences between groups at $p<$ 0.05 using Sigma Plot statistical software (v14, Systat Software Inc., USA).

\section{Results and discussion}

\section{Heavy metal content of tomato fruits}

In the current study, we investigated the heavy metal content of tomatoes from some areas of Uasin Gishu County, Kenya. The analytical results as compared with advisory guidelines are presented in Table 1. All the samples had detectable heavy metals, with $\mathrm{Pb}$ from Bahati estate recording the highest mean concentration of $43.20 \pm 0.31 \mathrm{mg} / \mathrm{kg}$. The concentration of the heavy metals varied between the studied areas $(p$ $<0.05)$, especially for $\mathrm{Pb}$.

Table 1. Heavy metal concentrations in edible parts of tomatoes from the sampled areas of Uasin Gishu, Kenya.

\begin{tabular}{|l|l|l|l|}
\hline Site & $\begin{array}{l}\text { Zinc } \\
(\mathrm{mg} / \mathrm{kg})\end{array}$ & $\begin{array}{l}\text { Lead } \\
(\mathrm{mg} / \mathrm{kg})\end{array}$ & $\begin{array}{l}\text { Cd } \\
(\mathrm{mg} / \mathrm{kg})\end{array}$ \\
\hline Huruma & $0.99 \pm 0.29$ & $\begin{array}{l}26.14 \pm \\
0.08\end{array}$ & $\begin{array}{l}2.15 \pm \\
0.21\end{array}$ \\
\hline Bahati & $1.49 \pm 0.04$ & $43.20 \quad \pm$ & $2.92 \quad \pm$ \\
& & 0.31 & 0.01 \\
\hline Chebaiywo* & $0.55 \pm 0.11$ & $16.07 \pm$ & $0.94 \pm 0.04$ \\
& & 0.23 & \\
\hline $\begin{array}{l}\text { WHO/FAO } \\
\text { limit }\end{array}$ & 50.00 & 0.10 & 0.05 \\
\hline
\end{tabular}

* Chebaiywo was used as a control site because it was speculated that it had low pollution as it is far away from industries.

All the concentrations of $\mathrm{Zn}$ recorded were below WHO recommended guideline of $50 \mathrm{mg} / \mathrm{kg}$. The highest concentration was $1.49 \pm 0.04 \mathrm{mg} / \mathrm{kg}$ recorded in samples from Bahati estate. The sequence followed was Bahati estate $>$ Huruma estate $>$ Chebaiywo village. The low concentrations of $\mathrm{Zn}$ recorded in the edible parts of tomatoes from all the sampled sites is corroborant with preceding reports $[2,4,7,22-$ 28] which reiterated that $\mathrm{Zn}$ levels in tomato fruits were among the lowest that were below compliance guidelines. However, some previous studies reported $\mathrm{Zn}$ in concentrations above advisory limits in tomato fruits $[29,30]$. The occurrence of $\mathrm{Zn}$ in environmental matrices is usually due to $\mathrm{Zn}$ used in old galvanized plumbing materials, $\mathrm{Zn}$ compounds in form of zinc-based paints, zinc alloys, dry cells, old and rusty galvanized roofing iron sheets and varnishes that may end up in the environment $[15,31]$. Zinc is an essential trace metal [32] required for normal functioning of the immune system, normal brain activity, foetal growth and development. However, immoderate intake may impair immune function and lower the levels of high-density lipoproteins [33, 34].

On the other hand, $\mathrm{Pb}$ was reported in the highest concentration $(p<0.05)$ among the heavy metals studied. Studies in Ghana [2], Kingdom of Saudi Arabia [22, 24], Jordan [28], Libya [26], Algeria, [4] and Nigeria [27] reported very low or undetectable levels of $\mathrm{Pb}$ in tomato fruits. In the neighbouring Tanzania and Ethiopia on the contrary, $\mathrm{Pb}$ was reported in tomato fruits in levels above compliance limits (range: below detection limit to $18.17 \mathrm{mg} / \mathrm{kg}$ and $3.63 \pm 0.11$ $\mathrm{mg} / \mathrm{kg}$, respectively) [7, 29]. The occurrence of 
$\mathrm{Pb}$ in urban areas have been grossly ascribed to the use of leaded petrol and inadvertent disposal of old lead batteries used in combustion-engined automobiles [15]. Lead is a toxin, a non-essential trace metal and the levels recorded in this study is deleterious to human health if ingested once or over a long period of time [35]. Moreover, it is a rival that outcompetes essential metals of analogous characteristics such as $\mathrm{Zn}$ and calcium. Besides, it has been criminated for renal failure and liver degradation in humans [36]. Lead also retards interactive, survival, growth, developmental and metabolic processes in addition to upregulating mucus synthesis, as well as inducing neurodevelopmental damage that causes decreased intelligence quotient and behavioural problems [37, 38]. It may also induce reproductive problems, premature birth or reduce foetal growth in expectant women [38].

As observed for $\mathrm{Pb}, \mathrm{Cd}$ was recorded in concentrations above the compliance guidelines. This did not agree with a previous study in Ghana [2] which reported that $\mathrm{Cd}$ recorded in tomatoes, cabbages, carrots, green pepper and onions were below WHO/FAO threshold. Gebeyehu and Bayissa [7], and Ali and Al-Qahtani [22] reported Cd levels of $0.56 \pm 0.05 \mathrm{mg} / \mathrm{kg}$ and 1.67 \pm 0.09 to $2.45 \pm 0.09 \mathrm{mg} / \mathrm{kg}$, respectively in tomato fruits from Egypt and some Saudi Arabian markets which were comparable to the values reported in this study. Other studies elsewhere [4, 24, 26, 27, 29] reported $\mathrm{Cd}$ in low or undetectable concentrations in tomato fruits while reported a higher $\mathrm{Cd}$ level of. Cadmium is typically found at low concentrations in the environment. However, indiscriminate use of phosphate-based agrochemicals, thoughtless disposal of nickel-cadmium batteries into the environment, $\mathrm{Cd}$ metal incineration and production might accrue its environmental concentrations [39-41]. Dietary ingestion of significant amounts of $\mathrm{Cd}$ causes renal and hepatic dysregulations, hypertension, lung cancer and diminished reproductive potential in humans [42-45]. Further, Cd may get absorbed in the human digestive system and is capable of penetrating through the placenta during pregnancy, inducing DNA and membrane dysregulations. Cadmium is also implicated in the etiology of calcium uptake inhibition and impairment of its subsequent retention in bones $[15,46,47]$.

The high levels of the heavy metals in samples from Huruma and Bahati estates is explained by the fact that these are situated in Eldoret city where there are many industries and activities, increasing the chances of environmental pollution by heavy metals and their subsequent uptake by the tomato plants. Overall, the chemical sequence followed by the metals in the tomato fruits in this study was $\mathrm{Pb}>\mathrm{Cd}>\mathrm{Zn}$. This is in congruence with previous observations which indicated that non-essential elements tend to be persistent in edible tissues [5, 39, 48] but the bioaccumulation capability of $\mathrm{Cd}$ usually takes a long time [39, 49]. 


\section{Human health risk assessment}

Continuous sub-lethal intake of non-essential trace metals such as $\mathrm{Pb}, \mathrm{Cd}$, arsenic and mercury have been known to cause human health effects, which become more pronounced after several years of exposure. In this study, the THQ method was used to assess the potential health risks of the heavy metals through their intake in the edible parts of tomato fruits. The estimated daily intakes ranged from $8.25 \times 10^{-4} \mathrm{mg} / \mathrm{kg} /$ day for samples from Chebaiywo village eaten by children to 2.59 $\times 10^{-1} \mathrm{mg} / \mathrm{kg} /$ day for fruits from Bahati estate consumed by adults (Table 2).

Table 2. Health risk assessment for consumption of tomatoes from the studied areas of Uasin Gishu County, Kenya.

\begin{tabular}{|c|c|c|c|c|c|c|}
\hline $\begin{array}{l}\text { Inde } \\
x\end{array}$ & Group & Site & Zinc & Lead & $\begin{array}{l}\text { Cad } \\
\text { miu } \\
\mathrm{m}\end{array}$ & $\begin{array}{l}\text { TTH } \\
\text { Q }\end{array}$ \\
\hline \multirow{6}{*}{ 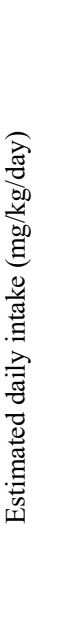 } & \multirow{3}{*}{$\frac{气}{\stackrel{\Xi}{\Xi}}$} & Huruma & $\begin{array}{l}1.49 \\
\text { E-03 }\end{array}$ & $\begin{array}{l}3.92 \\
\text { E-02 }\end{array}$ & $\begin{array}{l}3.23 \\
\text { E-03 }\end{array}$ & NA \\
\hline & & Bahati & $\begin{array}{l}2.24 \\
\text { E-03 }\end{array}$ & $\begin{array}{l}6.48 \\
\text { E-02 }\end{array}$ & $\begin{array}{l}4.38 \\
\text { E-03 }\end{array}$ & NA \\
\hline & & Chebaiywo & $\begin{array}{l}8.25 \\
\text { E-04 }\end{array}$ & $\begin{array}{l}2.41 \\
\text { E-02 }\end{array}$ & $\begin{array}{l}1.41 \\
\text { E-03 }\end{array}$ & $\mathrm{NA}$ \\
\hline & \multirow{3}{*}{ 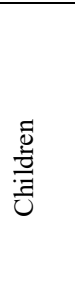 } & Huruma & $\begin{array}{l}5.94 \\
\text { E-03 }\end{array}$ & $\begin{array}{l}1.57 \\
\text { E-01 }\end{array}$ & $\begin{array}{l}1.29 \\
\text { E-02 }\end{array}$ & $\mathrm{NA}$ \\
\hline & & Bahati & $\begin{array}{l}8.94 \\
\text { E-03 }\end{array}$ & $\begin{array}{l}2.59 \\
\text { E-01 }\end{array}$ & $\begin{array}{l}1.75 \\
\text { E-02 }\end{array}$ & NA \\
\hline & & Chebaiywo & $\begin{array}{l}3.30 \\
\text { E-03 }\end{array}$ & $\begin{array}{l}9.64 \\
\text { E-02 }\end{array}$ & $\begin{array}{l}5.64 \\
\text { E-03 }\end{array}$ & NA \\
\hline \multirow{4}{*}{ 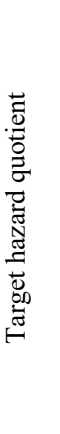 } & \multirow{3}{*}{$\frac{\stackrel{0}{E}}{\frac{\partial}{2}}$} & Huruma & $\begin{array}{l}3.73 \\
\text { E-01 }\end{array}$ & $\begin{array}{l}3.92 \\
\text { E01 }\end{array}$ & $\begin{array}{l}1.08 \\
\text { E-01 }\end{array}$ & $\begin{array}{l}3.97 \\
\text { E01 }\end{array}$ \\
\hline & & Bahati & $\begin{array}{l}5.60 \\
\text { E-01 }\end{array}$ & $\begin{array}{l}6.48 \\
\text { E01 }\end{array}$ & $\begin{array}{l}1.46 \\
\text { E-01 }\end{array}$ & $\begin{array}{l}6.55 \\
\text { E01 }\end{array}$ \\
\hline & & Chebaiywo & $\begin{array}{l}2.06 \\
\text { E-02 }\end{array}$ & $\begin{array}{l}2.41 \\
\text { E01 }\end{array}$ & $\begin{array}{l}4.70 \\
\text { E-02 }\end{array}$ & $\begin{array}{l}2.42 \\
\text { E01 }\end{array}$ \\
\hline & 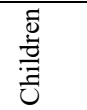 & Huruma & $\begin{array}{l}1.49 \\
\text { E0 }\end{array}$ & $\begin{array}{l}1.57 \\
\text { E02 }\end{array}$ & $\begin{array}{l}4.30 \\
\text { E-01 }\end{array}$ & $\begin{array}{l}1.59 \\
\text { E02 }\end{array}$ \\
\hline
\end{tabular}

\begin{tabular}{|l|l|l|l|l|l|c|}
\hline & Bahati & $\begin{array}{l}\mathbf{2 . 2 4} \\
\text { E0 }\end{array}$ & $\begin{array}{l}\mathbf{2 . 5 9} \\
\text { E02 }\end{array}$ & $\begin{array}{l}5.83 \\
\text { E-01 }\end{array}$ & $\begin{array}{l}\mathbf{2 . 6 2} \\
\text { E02 }\end{array}$ \\
& & Chebaiywo & 8.25 & $\mathbf{9 . 6 4}$ & 1.88 & $\mathbf{9 . 7 4}$ \\
& & E-01 & E01 & E-01 & E01 \\
\cline { 3 - 6 } & & & & & \\
\hline & & 4.00 & 1.00 & 3.00 & NA \\
& & E-03 & E-03 & E-02 & \\
\hline & & & & & \\
\hline
\end{tabular}

Values in bold show exceedance of Reference oral dose for the estimated daily doses or unity for the metal target hazard quotients. TTHQ: Total target hazard quotient, NA: Not Applicable.

The estimated daily intakes all exceeded the oral reference dose for $\mathrm{Pb}$, implying that there are possible health risks from consumption of tomatoes from the sampled sites. For noncarcinogenic risks, THQs were above 1 for $\mathrm{Pb}$ in fruits consumed by both adults and children. The THQs for $\mathrm{Zn}$ in tomato fruits consumed by children in Huruma and Bahati estates also exceeded 1, implying that consumption of tomatoes from these sites could have negative non-carcinogenic health impacts. This was confirmed by the TTHQs being greater than 1 for the sites. The differences in THQs for adults and children are usually attributed to the differences in the ingestion rates of food contaminated with heavy metals, body weights as well as the exposure times [2]. For this reason, children are more vulnerable to health risks associated with trace metal toxicity [50]. Further, the risk of consuming heavy metal contaminated foods can be more severe for special groups such as pregnant women and people with compromised immunity. However, it should be noted that tomato intake is usually a proportion of the food consumed, and therefore the levels of heavy metals may be augmented by intake from other 
sources such as fish and meat eaten as the main food.

Carcinogenic risk (CR), which is the incremental probability of an individual to develop cancer, over a lifetime, due to exposure to a potential carcinogen were estimated for $\mathrm{Pb}$ and $\mathrm{Cd}[51]$ (Table 3).

Table 3. Cancer risks through consumption of heavy metal contaminated tomatoes from the studied areas of Uasin Gishu, Kenya.

\begin{tabular}{|c|l|l|l|l|}
\hline Group & Site & Lead & Cadmium & $\begin{array}{l}\text { Total cancer } \\
\text { risk }\end{array}$ \\
\hline \multirow{3}{*}{ Adults } & Huruma & $3.33 \mathrm{E}-07$ & $1.23 \mathrm{E}-06$ & $1.563 \mathrm{E}-06$ \\
\cline { 2 - 5 } & Bahati & $5.51 \mathrm{E}-07$ & $1.66 \mathrm{E}-06$ & $2.18 \mathrm{E}-06$ \\
\cline { 2 - 5 } & Chebaiywo & $2.05 \mathrm{E}-07$ & $5.36 \mathrm{E}-07$ & $7.41 \mathrm{E}-07$ \\
\hline \multirow{3}{*}{ Children } & Huruma & $1.33 \mathrm{E}-06$ & $4.91 \mathrm{E}-06$ & $6.24 \mathrm{E}-06$ \\
\cline { 2 - 5 } & Bahati & $2.20 \mathrm{E}-06$ & $6.66 \mathrm{E}-06$ & $8.86 \mathrm{E}-06$ \\
\cline { 2 - 5 } & Chebaiywo & $8.19 \mathrm{E}-07$ & $2.14 \mathrm{E}-06$ & $2.96 \mathrm{E}-06$ \\
\hline $\begin{array}{l}\text { Ingestion cancer slope } \\
\text { factor }(\mathrm{mg} / \mathrm{kg} / \text { day })\end{array}$ & $8.50 \mathrm{E}-06$ & $3.80 \mathrm{E}-04$ & \\
\hline
\end{tabular}

The range of risks borderline by US EPA is $1 \times$ $10^{-4}$ to $1 \times 10^{-6}$ and is considered unacceptable if the risks are surpassing $1 \times 10^{-4}$ [52]. Considering intake of $\mathrm{Pb}$ and $\mathrm{Cd}$ through intake of contaminated tomato fruits, $\mathrm{CR}$ ranged from $2.05 \times 10^{-7}$ to $6.66 \times 10^{-6}$ for both groups. The calculated CR values were lower than $1 \times 10^{-4}$, indicating that there are no potential cancer risks from consumption of tomatoes in the studied sites of Uasin Gishu County.

\section{Conclusion}

The current study has shown that tomato fruits consumed in Huruma and Bahati estates of Eldoret town, and Chebaiywo village of Kesses in Uasin Gishu County are contaminated with heavy metals: $\mathrm{Zn}, \mathrm{Pb}$ and $\mathrm{Cd}$. Daily consumption of the fruits may lead to deleterious noncarcinogenic health risks, and the risk is highest for residents in Bahati estate. A study using a large number of samples from other estates of Eldoret city should be undertaken, especially in the low-income estates which houses the inextricably poor and vulnerable population. The heavy metal content of soils in these areas should be evaluated.

\section{Acknowledgements}

The authors are grateful to the World Bank and the Inter-University Council of East Africa for the fellowship awarded to DMN and TO through the Africa Center of Excellence II in Phytochemicals, Textiles and Renewable Energy (ACE II-PTRE) at Moi University, Kenya which made this concerted short communication possible.

\section{References}

[1] Omara T, Nnankabirwa R, Nassazi W, Nakabuye BV, Musau B. Spectroscopic screening of assorted pigmented vegetables and fruits common in Metropolitan Kampala culinary recipes for anthocyanins. Int J Food Sci Nutr. 2018; 3: 282-290.

[2] Ametepey ST, Cobbina SJ, Akpabey FJ, Duwiejuah AB, Abuntori ZN. Health risk assessment and heavy metal contamination levels in vegetables from Tamale Metropolis, Ghana. Int J Food Contam. 2018; 5: 5.

[3] Cui YJ, Zhu YG, Zhai RH, et al. Transfer of metals from soil to vegetables in an area near a smelter in Nanning, China. Int J Environ. 2010; 30: 785-791.

[4] Bounar A, Boukaka K, Leghouchi E. Determination of heavy metals in tomatoes cultivated 
under green houses and human health risk assessment. Qual Ass Safety Crops Foods. 2020; 12: 76-86.

[5] Nteziyaremye P, Omara T. Bioaccumulation of priority trace metals in edible muscles of West African Lung Fish (Protopterus annectens Owen, 1839) from Nyabarongo River, Rwanda. Cogent Environ Sci. 2020; 6: 1779557. https://doi.org/10.1080/23311843.2020.1779557

[6] Omara T, Nteziyaremye P, Akaganyira S, Opio D W, Karanja LN, Nyangena DM, Kiptui BJ, Ogwang R, Epiaka SM, Jepchirchir A, Maiyo A. Physicochemical quality of water and health risks associated with consumption of African lung fish (Protopterus annectens) from Nyabarongo and Nyabugogo rivers, Rwanda. BMC Res Notes. 2020; 13: 66. https://doi.org/10.1186/s13104020-4939-z.

[7] Gebeyehu HR, Bayissa LD. Levels of heavy metals in soil and vegetables and associated health risks in Mojo area, Ethiopia. PLoS ONE. 2020;15(1): e0227883.

[8] Angiro C, Abila PP, Omara T. Effects of industrial effluents on the quality of water in Namanve stream, Kampala Industrial and Business Park, Uganda. BMC Res Notes. 2020; 13: 220.

[9] Jolly YN, Islam A, Akbar S. Transfer of metals from soil to vegetables and possible health risk assessment. Springer Plus. 2013; 2: 385-391.

[10] Ndwiga T. Selected trace elements in domestic water boreholes and their implications on human health in Huruma estate, Eldoret Municipality, Uasin-Gishu County, Kenya. J Environ Protect. 2014; 5: 65-70.

[11] Shieunda OR, Neyole E, Omuterema S, Orat F. Assessment of key point sources of heavy metals (lead, cadmium and chromium): A case of River Sosiani. Appl Ecol Environ Sci. 2019; 7: 128-134.

[12] Mausi G, Simiyu G, Lutta S. Assessment of selected heavy metal concentrations in selected fresh fruits in Eldoret town, Kenya. J Environ Earth Sci. 2014; 4: 1-8.

[13] Jepkoech JK, Simiyu GM, Arusei M. Selected heavy metals in water and sediments and their bioconcentrations in plant (Polygonum pulchrum) in
Sosiani river, Uasin Gishu County, Kenya. J Environ Protect. 2013; 4 : 796-802.

[14] Cherop CK, Otieno AC, Koskei P. Heavy metals in pig livers; A case of Munyaka Estate-Uasin-Gishu County, Kenya. Afr J Educ Sci Technol. 2018; 4: 38-46.

[15] Omara T, Ogwang R, Ndyamuhaki S, Kagoya S, Kigenyi E, Musau B, Adupa E. Spectroscopic analysis of selected priority trace metals in the extant East African gilled lungfish (Protopterus amphibius) in Lira municipal lagoon and its edibility health risk. Sci J Anal Chem. 2018; 6: $38-45$.

[16] Omara T, Karungi S, Kalukusu R, Nakabuye BV, Kagoya S, Musau B. Mercuric pollution of surface water, superficial sediments, Nile Tilapia (Oreochromis nilotica Linnaeus 1758 [Cichlidae]) and yams (Dioscorea alata) in auriferous areas of Namukombe stream, Syanyonja, Busia, Uganda. PeerJ. 2019; 7: e7919. http://doi.org/10.7717/peerj.7919.

[17] Ordonez A, Alvarez R, Charlesworth S, De Miguel E, Loredo J. Risk assessment of soils contaminated by mercury mining, Northern Spain. J Environ Monit. $2011 ; 13: 128-136$.

[18] Macrotrends. Kenya Life Expectancy 19502020.

https://www.macrotrends.net/countries/KEN/kenya/lifeexpectancy. Accessed 25 May 2020.

[19] Wang X, Sato T, Xing B, Tao S. Health risks of heavy metals to the general public in Tianjin, China via consumption of vegetables and fish. Sci Total Environ. 2005; 350: 28-37.

[20] USEPA. Integrated risk information system. United States, Environmental Protection Agency, Washington, DC, USA. 2017.

[21] Lim HS, Lee JS, Chon HT, Sager M. Heavy metal contamination and health risk assessment in the vicinity of the abandoned Songcheon Au-Ag mine in Korea. J Geochem Explor. 2008; 96: 223-30.

[22] Ali MHH, Al-Qahtani KM. Assessment of some heavy metals in vegetables, cereals and fruits in Saudi Arabian markets. Egypt J Aquat Res. 2012; 38 : 31-37. 
[23] Bvenura C, Afolayan AJ. Heavy metal contamination of vegetables cultivated in home gardens in the Eastern Cape. South Afr J Sci. 2012; 108 : 1-6.

[24] Oteef MDY, Fawy KF, Abd-Rabboh HSM, Idris AM. Levels of zinc, copper, cadmium, and lead in fruits and vegetables grown and consumed in Aseer Region, Saudi Arabia. Environ Monit Assess. 2015; 187: 676.

[25] Tasrina RC, Rowshon A, Mustafizur AMR, Rafiqul I, Ali MP. Heavy metals contamination in vegetables and its growing soil. J Environ Anal Chem. 2015; $2: 142$.

[26] Elbagermi MA, Edwards HGM, Alajtal AI. Monitoring of heavy metal content in fruits and vegetables collected from production and market sites in the Misurata area of Libya. ISRN Anal Chem. 2012 : 1-5. doi:10.5402/2012/827645.

[27] Ndinwa GCC, Mirsm A, Chukumah CO, et al. Determination of heavy metals in tomato (Solanum lycopersicum) leaves, fruits and soil samples collected from Asaba Metropolis, Southern Nigeria. Canadian J Pure Appl Sci. 2014; $8:$ 2715-2720.

[28] Salem NM, Albanna LS, Awwad AM. Toxic heavy metals accumulation in tomato plant (Solanum lycopersicum). ARPN J Agric Biol Sci. 2016; 11: 399-404.

[29] Lugwisha EH, Othman CO. Heavy metal levels in soil, tomatoes and selected vegetables from Morogoro region, Tanzania. Int J Environ Monit Anal. 2016; 4 : 8288.

[30] Bosiacki M, Tyksiñski W. Lead, zinc, iron and manganese content in edible parts of some fresh vegetables sold on markets in Pozincañ. J Elementol. 2009; 14 : 1322.

[31] WHO. Guidelines for drinking-water quality, 4 th edition, incorporating the 1 st addendum. Geneva, Switzerland. 2017. 631p.

[32] Hambidge KM, Krebs NF. Zinc deficiency: a special challenge. J Nutr. 2007; 137: 1101-5.

[33] Harmanescu M, Alda LM, Bordean DM, Gogoasa L, Gergen L. Heavy metals health risk assessment for population via consumption of vegetables grown in old mining area, a case study: Banat County, Romania. Chem Cent J. 2011; 5: 64-73.

[34] Johnson AR, Munoz A, Gottlieb JL, Jarrard DF. High dose zinc increases hospital admissions due to genitourinary complications. J Urol. 2007; 177: 639-643.

[35] Badr AM, Mahana NA, Eissa A. Assessment of heavy metal levels in water and their toxicity in some tissues of Nile Tilapia (Oreochromis niloticus) in River Nile basin at Greater Cairo, Egypt. Glob Vet. 2014; 13: $432-43$.

[36] Salem HM, Eweida EA, Farag A. Heavy metals in drinking water and their environmental impact on human health. In: The International Conference for Environmental Hazard Mitigation ICEHM 2000. 9-12 September 2000, Cairo University, Cairo, Egypt, 2000.

[37] Eisler R. Lead hazards to fish, wildlife and invertebrates: A synoptic review. In; Contaminant Hazard Reviews, Report 14; Biological Report 85(1.14). U.S. Department of the Interior, Fish and Wildlife Service, Laurel, MD, pp. 1-14, 1988.

[38] EPA. Basic Information about Lead in Drinking Water. https:/www.epa.gov/ground-water-and-drinkingwater/basic-information-about-lead-drinking-water.

Acessed 10 May 2020.

[39] Ahmed ASS, Sultana S, Habib A, Ullah H, Musa N, Hossain MB, Sarker MSI, Rahman MM. Bioaccumulation of heavy metals in some commercially important fishes from a tropical river estuary suggests higher potential health risk in children than adults. PLoS ONE. 2019; 14: e0219336.

[40] Bustueva KA, Revich BA, Bezpalko LE. Cadmium in the environment of three Russian cities and in human hair and urine. Arch Environ Health. 1994; 49: 284288.

[41] Bennet-Chambers M, Davies P, Knott B. Cadmium in aquatic ecosystems in Western Australia: A legacy of nutrient-deficient soils. J Environ Manage. 1999; $57: 283-295$. 
[42] Suruchi, Pankaj K. Assessment of heavy metal contamination in different vegetables grown in and around urban areas. Res J Environ Toxicol. 2011; 5 : 162-79.

[43] Guerra F, Trevizam AR, Muraoka T, Marcante NC, Canniatti-Brazaca SC. Heavy metals in vegetables and potential risk for human health. Sci Agric. 2012; 69 : 5460.

[44] Agency for Toxic Substances and Disease Registry (ATSDR). Toxicological profile for cadmium. Atlanta: US Department of Health and Human Services. 2012.

[45] Waalkes MP. Cadmium carcinogenesis. Mutat Res. 2003; 533 : 107-120.

[46] El-Moselhy KM, Othman AI, Abd El-Azem H, El-Metwally MEA. Bioaccumulation of heavy metals in some tissues of fish in the Red Sea, Egypt. Egypt J Basic Appl Sci. 2014; 1: 97-105.

[47] WHO. Evaluation of certain food additives and contaminants. In: Sixty-First Report of the Joint FAO/WHO Expert Committee on Food Additives. Geneva: WHO (WHO Technical Series, 922). 2004.

[48] Traina A, Bono G, Bonsignore M, Falco F, Giuga M, Quinci EM, Vitale S, Sprovieri M. Heavy metals concentrations in some commercially key species from Sicilian coasts (Mediterranean Sea): Potential human health risk estimation. Ecotoxicol Environ Saf. 2019; 168: 466-478.

[49] Zhong W, Zhang Y, Wu Z, Yang, R, Chen X, Yang J, Zhu L. Health risk assessment of heavy metals in freshwater fish in the Central and Eastern North China. Ecotoxicol Environ Saf. 2018; 157: 343-349.

[50] Benson NU, Anake WU, Essien JP, Enyong P, Olajire AA. Distribution and risk assessment of trace metals in Leptodius exarata, surface water and sediments from Douglas creek in the Qua Iboe Estuary. J Taibah Univ Sci. 2017; 11: 434-449.

[51] USEPA. USEPA Regional Screening Level (RSL) Summary Table. http://www.epa.gov/regshwmd/risk/human/Index.htm. Accessed 15 March 2020.
[52] EPA. Edition of the Drinking Water Standards and Health Advisories. 2012: EPA 822-S-12-001. Washington, DC: Office of Water US Environmental Protection Agency. 2012. 